International Review of Social History 44 (1999), Supplement, pp. IOI-I22

(C) 1999 Internationaal Instituut voor Sociale Geschiedenis

\title{
Sex Workers or Citizens? Prostitution and the Shaping of "Settler" Society in Australia*
}

\author{
RaELENE FRANCES
}

\section{INTRODUCTION}

The history of prostitution, defined as the commercial exchange of sexual services, provides a fertile ground for the study of the intersections between gender, race and class. Obviously, the sale of sexual labour has implications for constructions of gender, although the specific implications may change with time. Commercial sex offers particularly sharp insights into the ways in which gender considerations intersect with class and race because of the physical intimacy and potential for procreation involved in the sex act. Prostitution literally forces societies to come face to face with their assumptions about and attitudes to class and race hierarchies and relationships. The Australian case is especially useful for studying these relationships because of the imbalance in the ratio of men to women which has characterized colonial society generally and certain types of communities in particular, and the ways in which this imbalance affected some classes and ethnic groups more than others. Colonial Australia also provides a complex tapestry of ethnic/racial issues because it included divisions not just between "white" settlers and indigenous Aborigines, but also between both of these groups and various groups of immigrant, "coloured" workers. In the twentieth century, when demographic patterns became more balanced in gender terms and more homogenous in racial terms, the international sex industry continued to be important because it played a part in Australia's quest for recognition as an independent member of the community of "civilized", white, nations. Finally, the process of reassessing Australia's place in the world was intimately connected to a reassessment of Australia's domestic policies, both in relation to prostitution generally and to the sexual exploitation of Aboriginal women.

Prostitution has thus played a singular role in the establishment and development of white society in Australia. From the outset, the sexual availability of certain classes of women was seen by governments as an important element in the maintenance of civil and social order. And in every case, the choice of which women should fill the role of public prostitute and which men they should service was intimately connected to official visions of a sociery constructed in relation to a particular configuration of class, race

* My thanks to the editors, Bruce Scates and Ann McGrath for comments on an earlier version of this article. I am also indebted to Michèle Langfield and Alison Holland for particularly helpful references and suggestions. 
and gender factors. However, the precise relationship of these three factors varied considerably across time, particularly as a result of shifting racial attitudes and changing demographic structures. This article will chart the broad chronology of these developments from first white settlement in 1788 to the beginning of World War Two. However, the focus of the paper will be on the first three decades of the twentieth century because this period has been the least studied. I argue that the treatment of prostitutes and prostitution in Australia reflected changing priorities and objectives in government policy. Specifically, that Australian governments used immigration controls originally designed to ensure a racially "white Australia" to exclude "white" women whose sexuality was seen to pose a more subtle threat to the young white nation. Moreover, the case of prositution and immigration control provides insight into the shifting dynamics operating at both an international and Australian level to reshape the racial, class and gender characteristics of settler society in Australia.

\section{PROSTITUTION IN CONVICT SOCIETY: IMPERIAL WHOREMASTERS?}

The first white settlements were penal colonies where men outnumbered women by an average of six to one. Feminist historians such as Ann Summers have argued that convict women in these settlements were in a state of "enforced whoredom", with young women transported for relatively trivial offences in order to provide sexual partners for male convicts, their overseers and guards. British authorities hoped thereby to minimize the incidence of sodomy amongst convict men and also to reduce their inclination for rebellion. Prostitution was thus tolerated, even encouraged, as an antidote to more serious social and civil disorders. ${ }^{\mathrm{T}}$

The founding Governor, Arthur Phillip, had a vision for the new society in New South Wales which was carefully constructed with regard to racial, gender and class hierarchies. Convict men would be provided with access to convict women in order to satisfy their lusts, which, he presumed, were more urgent and dangerous than the lusts of gentlemen. The more virtuous amongst the women, he hoped, might be inclined to form attachments to individual men and marry them. Phillip also believed that Aboriginal women might, in time, marry and live with convict men. For that other class of single men, the soldiers garrisoned to secure order, he envisaged importing Polynesian women whom they would marry. Thus, the original white settlement in Australia was founded on a vision which included a careful hierarchy, with Aboriginal women on the same level as convicts; Polynesian women on a higher level than either Aborigines or convicts, of 
equal status to soldiers. Above them all, of course, were the gentlemen officers, who would bring wives of their own race and class with them. ${ }^{2}$

The reality turned out somewhat differently to this cosy scheme. The limited opportunities for women in other occupations, and the high demand for their sexual services, meant that there was indeed a high incidence of prostitution in convict society. And many convict women formed long-term attachments, including marriage, with convict men. However, Phillip's dreams of racial harmony evaporated in the first year of settlement. Rape was more characteristic of male convict interaction with Aboriginal women than cohabitation: the lower levels of white society had a rather different hierarchy in mind, with Aborigines decidedly below all whites, including convicts. The scheme to import Polynesian women from the islands never eventuated, as on reflection Phillip decided this would be cruel to the women. ${ }^{3}$ Meanwhile, convict women did not respect the class boundaries of Phillip's scheme, forming de facto and legal marriages with men from all colonial classes, including officers and governors. Often skilled at making calculated decisions about their best financial advantage, many women seized the opportunity to secure a socially and financially advantageous marriage rather than take their chances in the labour market, including the sexual labour market. Class hierarchies which may have been enforceable in Britain were unable to withstand the pressures of a distant and demographically-skewed society. Likewise, racial hierarchies which seemed desirable from the comfortable distance of England could not withstand the realities of the violent racial interaction which characterized the early years of the colony. ${ }^{4}$

\section{THE LATE COLONIAL PERIOD: PROSTITUTION IN THE "WORKERS" PARADISE"}

Transportation of convicted felons to eastern Australia ceased in 1851. This coincided with the gold rushes which brought thousands of prospectors from all over the world keen to try their luck. The new wealth generated both by the gold that was found and the newly arrived colonists themselves produced a society which was anxious to forget its convict past and establish

2. Patricia Grimshaw, Marilyn Lake, Ann MoGrath and Marian Quartly (eds), Creating a Nation (Melbourne, 1994), pp. 30-31.

3. Letter Governor Phillip to Lord Sydney, is May 1788, Historical Records of Australia, series I, vol. 1, p. 23.

4. There is a very large literature on the fate of convict women. More recent work includes Deborah Oxley, Convict Maids (Melbourne, VIC, 1997); Joy Damousi, Depraved and Disorderly (Melbourne, VIC, 1997); Kay Daniels, Convict Women (Sydney, NSW, 1998); see also Marian Aveling, "Bending the Bars: Convict Women and the State", in Kay Saunders and Raymond Evans (eds), Gender Relations in Australia: Domination and Negotiation (Sydney, NSW, 1992), pp. 144-I57. For Aboriginal women, see Mary Anne Jebb and Anna Haebich, "Across the Great Divide: Gender Relations on Australian Frontiers", in Saunders and Evans, Gender Relations in Australia, pp. 20-4I. 
a reputation as a free and democratic society - the so-called "workers' paradise". Once again, prostitution played an important part in this revised vision. However, that role was by no means uniform across time and space. The precise role prostitution played in any particular part of Australia depended on sex ratios in specific groups of colonial sociery and evolving racial attitudes. Where men continued to predominate, such as in newlyopened gold mining areas or amongst groups of immigrant workers, prostitution was practised openly and was tolerated by the state. Where the "frontier" phase of settlement had passed or where sex ratios had equalized, state tolerance declined and policing priorities became more responsive to social purity pressure groups. These latter groups argued from the perspective of Christian, family and feminist values for the curtailment of public displays of prostitution, or more extremely, its total repression. ${ }^{5}$

In old convict towns like Hobart, the eradication of visible prostitution was part of a self-conscious move to distance a newly free society from its convict past. Prostitute women bore the moral burden of the "convict stain", whether or not they had in fact been transported or convicted. As Kay Daniels and Mary Murnane have shown, prostitute women were also forced to carry a greater burden - the responsibility for the health of visiting British sailors. The British Navy pressured local authorities in Tasmania to pass legislation similar to the notorious British Contagious Diseases Acts of the r86os, forcing suspect women to undergo medical examination for venereal disease and incarceration if found infected. As in Britain, class-based judgments about female sexuality were used to control the sexuality of urban unrespectable poor women, using supposedly public health measures. ${ }^{6}$ In Western Australia, police, magistrates and government medical officers achieved a similar outcome by exploiting the flexibility inherent in the vagrancy laws.'

It was in northern Australia, however, that we see commercial sex more clearly tied up with issues of race/ethnicity as well as class. In the late nineteenth century, Aboriginal populations in northern Australia still outnumbered whites and were still undergoing a process of subjugation by violence, starvation and persuasion. The sexual exploitation of black women by white men was an intrinsic part of this process. The "economy of sex" which evolved around Aboriginal women became, in many cases, the only

5. There is no comprehensive history of prostitution in Australia. Kay Daniels's edited collection, So Much Hard Work: Women and Prostitution in Australian History (Melbourne, VIC, 1984), is a series of case studies rather than an overview.

6. Kay Daniels and Mary Murnane, "Prostitutes as 'Purveyors of Disease': Venereal Disease Legislation in Tasmania, 1868-1945", Hecate, 5 (1979), Pp. 5-21; also Kay Daniels, "Prostitution in Tasmania during the Transition from Penal Settement to a Civilised Society", in Daniels (ed.), So Much Hard Work, pp. 15-85.

7. Raelene Davidson, "Dealing with the Social Evil': Prostitution and the Police in Perth and on the Eastern Goldfields I895-1924", in Daniels (ed.), So Much Hard Work, pp. I62-19I. 
way in which remnant Aboriginal groups could survive after the arrival of white pastoralists and miners. White men's sexual access to black women became both a means to and a symbol of the dispossession and defeat of Aboriginal people. ${ }^{8}$

In the north, however, the "coloured problem" did not just apply to Aboriginal people. The racial situation was further complicated by the presence of large numbers of immigrant workers from South-East Asia, China, Japan and the Melanesian Islands. With the exception of the Japanese, the overwhelming majority of these workers were men. The arrival of these "coloured" workers coincided with a hardening of racial attitudes amongst white Australians, who eagerly embraced the scientific racism of Social Darwinism to justify white dominance. Racial theories such as Social Darwinism, based on the assumption of physically distinct races, focused popular and government attention on the implications of interracial sex for white settler society. As Raymond Evans' work on Queensland has shown, colonial politicians and bureaucrats were only too willing to tolerate or even encourage the presence of Japanese prostitutes precisely because they offered a racially acceptable solution to the problem of the sexual desires of a large non-white male workforce. According to this logic, if Japanese women did not perform this service, "coloured" workers would seek out the services of white prostitutes or rape white women, both outcomes clearly having the potential to undermine the "purity" of the white race by producing children of mixed racial parentage.? But there was more to contemporary white objections to miscegenation than racial interbreeding. As Philippa Levine has noted in the Indian context, the presence of European prostitutes in mixed-race colonies "challenged white supremacy in distinctive and critical ways, which reveal dramatically and vividly the importance of sexual politics in colonial rule [...] the symbolic servitude of a white woman to a black man would radically and fatally undermine the basis of colonial rule". ${ }^{\text {to }}$

From the late nineteenth century we also see an increasing elaboration of the concept of "whiteness". As Ruth Frankenberg has illustrated, "whiteness changes over time and space" and is also a relational category, "one that is coconstructed with a range of other racial and cultural categories, with class and with gender". ${ }^{\text {II }}$ In late colonial Australia, people of non-Anglo-Saxon descent were increasingly distinguished from the "real" white Australians: those of British descent. In Western Australia, for example, governments

8. Jebb and Haebich, "Across the Great Divide". See also Deborah Bird Rose, Hidden Histories (Melbourne, VIC, and Canberra, CT, 1992).

9. Raymond Evans, "Soiled Doves': Prostitution in Colonial Queensland", in Daniels (ed.), So Much Hard Work.

Io. Philippa Levine, "Venereal Disease, Prostitution and the Politics of Empire: the Case of British India", Journal of the History of Sexuality, 4 (1994), p. 593.

II. Ruth Frankenberg, White Women, Race Matters: the Social Construction of Whiteness (Minneapolis, MN, 1993), p. 236. 
and police encouraged the presence of "foreign" prostitutes, not just Japanese but also French and Italian. They did this partly for purely racial reasons: as in Queensland, such women protected white women (here defined in the narrower, British, sanse) from contamination by "coloured" men, such as the Afghan camel-drivers. More importantly in this case, however, was the protection they gave to the popular white settler vision of itself as a society. The extent to which women had to resort to prostitution as a form of economic survival became an important gauge of the civilized and progressive standing of a society. ${ }^{\mathrm{I2}}$ The visible presence of large numbers of "foreign" women, be they Japanese, Italian or French, thus allowed local commentators to congratulate themselves on the advanced status of Western Australia. In 1915 a West Australian politician, the Honourable R.H. Underwood, told the Legislative Assembly that:

We can take credit, and I think should take credit to ourselves in WA for our social conditions when we reflect that the supply of prostitutes in this country has given out. Most honourable members know that prostitutes in WA are supplied chiefly from France, Japan, and Italy. As a matter of fact the Australian social system has kept the Australian women out of it. ${ }^{13}$

Again, the parallels with the Indian case are striking, where authorities comforted themselves with the thought that the growing number of European prostitutes were Catholics or Jews, not "English girls". ${ }^{14}$

Expressed another way, white commentators such as Underwood believed their society was superior to both Asian and continental European society partly because of Australia's allegedly superior, more egalitarian class structure. In a society which still had a preponderance of men over women, the existence of "foreign" prostitution was critical to the maintenance of this belief because it allowed contemporaries to turn a blind eye to the majority of the urban prostitute population - Australian-born women of British descent. ${ }^{15}$ To contemplate the significance of the latter group of prostitutes would have been to admit that even if Australia was a paradise for (white) working men, it did not provide so well for white working women. The ethnic/racial dimensions of prostitution thus obscured the gender realities of late colonial settler society. Underwood's statement also suggests how the focus on some forms of racial/ethnic difference could deflect attention from other, equally fundamental racial divisions. The "Australian women"

12. Raelene Frances, "Australian Prostitution in International Context", Australian Historical Studies, I06 (1996), pp, 127-141.

I3. Hon. R.H. Underwood, Western Australian Parliamentary Debates: Legislative Assembly, $5 \mathrm{I}$ (7 September 1915), p. 637.

14. Levine, "Venereal Disease, Prostitution and the Politics of Empire", p. 593.

I5. Raelene Davidson, "As Good a Bloody Woman as Any Other Bloody Woman': Prostitutes in Western Australia, 1895-1939", in Patricia Crawford (ed.), Exploring Women's Past (Sydney, NSW, 1985). 
identified by Underwood were by implication all white women. Aboriginal women were thus effecrively rendered invisible and irrelevant to his conception of Australian society. Racial/ethnic divisions reinforced class and gender divisions, but different kinds of racial/ethnic divisions were also mutually reinforcing.

\section{THE TWENTIETH CENTURY: ACHIEVING AND MAINTAINING A WHITE AUSTRALIA}

The six Australian colonies joined together in $190 \mathrm{I}$ to form a federated Commonwealth of Australia. The first Act of the new federal parliament was the 190I Immigration Restriction Act. It was to provide the cornerstone of the new nation, a nation founded above all on the idea of a "white Australia". While Social Darwinist and eugenicist ideas achieved wide currency throughout Western societies in the late nineteenth and early twentieth centuries, in Australia they assumed a particular importance. The idea of "survival of the fittest" when applied to human "races" justified the dispossession and apparent demise of Australia's original inhabitants. Scientific racism had an added significance, though, because of Australia's history as an outpost of European civilization in Asia: ever-conscious of the "teeming hordes" of "coloured aliens" directly to the north, white Australians, who, by I90I, numbered around four million, had become increasingly nervous about the presence of Asians within their borders and increasingly determined to expel them. Expulsion seemed the most effective way of stemming the tide of "Asiatics" who threatened to swamp the relatively small numbers of white Australians. White Australians were also hostile to a mixed-race society because they feared that Asian values and practices would undermine what they saw as a superior Australian way of life. The labour movement, in particular, feared that cheaper Asian labour would undermine the conditions of Australian workers. Anti-Asian sentiment also had more overtly racist elements, with allegations that the Chinese (almost all of whom were men) debauched innocent white girls, engaged in sodomy and other vices, such as opium smoking and gambling. ${ }^{16}$ Those who drafted the constitution and sat in the parliaments of the newly-federated Commonwealth had a (although admittedly imprecise and contested) view of Australia as an homogenous white society, based firmly on British institutions and peoples, but incorporating the democratic, egalitarian aspects of a new society. Until late in the nineteenth century, class could cancel out colour but not gender as a qualification for citizenship, so that, for example, male

16. A.T. Yarwood, Attitudes to Non-European Immigration (Sydney, NSW, 1968); idem, Asian Migration to Australia: the Background to Exclusion 1896-1913 (Sydney, NSW, 1964). See also A.T. Yarwood and M.J. Knowling, Race Relations in Australia (Sydney, NSW, 1982) and Andrew Markus, Australian Race Relations (Sydney, NSW, 1994). 
Aboriginal and Chinese property owners could qualify for the vote in colonial legislatures. By the early twentieth century racial background assumed greater significance than either class or gender. White people of all classes, both male and female, had privileged rights as citizens, while non-whites, whether indigenous Aborigines or immigrants, were either excluded completely or relegated to the status of second-class citizens. ${ }^{17}$ Immigration control played a critical part in establishing and maintaining this hierarciny.

The federation of the Australian colonies also coincided with the advent of two new, albeit related, forces in Australian and international politics. Although some Australian colonies had already given women the right to vote in parliamentary elections, the Commonwealth Constitution gave all white women the right to vote for its parliaments. Feminist politics therefore assumed a newfound importance in the twentieth century. Secondly, the first decade of the twentieth century saw the establishment of an international movement concerned to abolish the sexual traffic in women and girls. Both these forces were to have an impact on the way in which immigration laws were enforced in Australia, giving a new, sexualized and gendered meaning to what began as a policy of racial exclusion.

To understand this process, however, we need to understand how the Immigration Restriction Act operated. The history of the Immigration Restriction Act has to date focused, not surprisingly, on the racial aspects of this so-called "white Australia policy" ${ }^{18}$ My task here is to explore this history from a different angle, to examine how issues of gender, sexuality and class intersected with racial concerns in deciding who would be excluded from Australia. In so doing, I argue that the connections between race, class and gender outlined above for the colonial period were just as relevant for the early twentieth century, although the precise permutations changed over time.

Although popularly understood both within and outside Australia as a policy of racial exclusion, the Immigration Restriction Act was not framed in racial terms. On the contrary, there was no specific mention of racial attributes in the selection of immigrants, the primary mechanism for exclusion being a dictation test in a European language. The notorious dictation test was originally used in late nineteenth-century Natal to keep Asians from British colonies out of British African colonies. It was seized upon in the newly-federated Australian Commonwealth as a way of keeping out so-called "coloured" races without (it was hoped) giving obvious offence

17. For an excellent account of this process, see Patricia Grimshaw and Katherine Ellinghaus, "White Women, Aboriginal Women and the Vote in Western Australia", in Studies in Western Australian History, forthcoming women's suffrage centenary special issue.

18. Ibid., fn. 14. Also, Myra Willard, History of the White Australia Policy (London, 1923); A.C. Palfreeman, The Administration of the White Australia Policy (Sydney NSW, 1967); Sean Brawley, The White Peril: Foreign Relations and Asian Immigration to Australasia and North America Igro78 (Kensington, NSW, 1995). 
to other citizens of the British Empire or her allies in Asia. Those excluded were expected to believe that it was not the colour of their skin but their spelling that Australia found objectionable. The test was used in the twentieth century to exclude not just "coloureds" but also others considered subversive to Australia's political institutions. The case of the Communist Egon Kisch, exciuded in 19.4 after failing a test in Gaelic, is well-known. ${ }^{19}$ Less well-known is the use made of this dictation test to exclude persons of suspect sexuality.

The tardiness of historians in recognizing this aspect of the "white Australia policy" is surprising, given the publicity to such deportations in the I920s and 1930s. Several sensational cases involving French and Italian nationals in the late 1920 and early 1930 s were widely reported in the popular press. On each occasion, the processes of exclusion were made only too transparent. For example, Smith's Weekly in April 1929 carried a report of a French woman of ill-repute who had married an "ex-digger" (that is, a returned Australian soldier) to escape deportation, but who had subsequently returned to her former acquaintances. "She was hailed before the customs office charged with being a prohibited immigrant. A dictation test in German was applied, and, failing to pass it, she was sentenced to six months imprisonment and deportation. ${ }^{20}$ Four days later the Sun (Sydney) reported the deportation of one of her associates after failing to pass a dictation test in English. The article made it clear why he was being deported, reporting the item with a bold caption: "WHITE SLAVERY INQUIRY". The Sun Pictorial carried a version of the same story under the heading: "WEALTHY FRENCHMAN AND DICTATION TEST MIGRATION CHARGE. ${ }^{{ }_{21}}$ The public was left in no doubt as to the connection between dictation tests, deportations and allegations of white slavery/prostitution. Indeed, the Crown prosecutor was reported by the Sun as saying: "The Crown could deport anyone it chose, but wanted to show the court and the public that proceedings had been taken on proper grounds." To add weight to its action, the court and the press were informed that the government had only acted after receiving "a communication from the White Slavery Committee of the League of Nations" ${ }^{22}$ Earlier cases made the same connection. In July 1928, the Melbourne Argus reported that two French women, residents of Perth, were to be deported after failing to pass the language test in English. "The police alleged that they kept a house of ill-fame. ${ }^{23}$ The Melbourne Age went into more detail, reporting how the women had lived in Egypt before coming to Australia with £2,000 which

19. The most recent account of this episode is in Stuart Macintyre, The Reds: The Communist Party of Australia from Origins to Illegality (Sydney, NSW, 1998), pp. 270-273.

20. Smith's Weekly, 20 April 1929.

21. Sun Pictorial, 20 April 1929.

22. Sun, 24 April 1929.

23. Argus, 13 July 1928. 
they invested in a house in Roe Street, Perth. As most Australians were aware, Roe Street was a notorious red-light district, while European women who lived in Egypt were immediately suspect. ${ }^{24}$ The sdelaide Advertiser's report of the court case included the defence offered by the two sisters concerned. They argued that the Immigration Act should not have been applied to them as they had made it clear by their investments that they intended to settle in Australia permanently. As such they were "citizens", not "immigrants". The Chief Justice was unconvinced, pointing out that the dictation test could be administered any time within the first three years after arrival. "Persons who entered Australia could do so only subject to Australia's terms, and, so to speak, were here for the first three years on approval. ${ }^{25}$ Clearly, Australia did not approve of prostitutes and therefore had the right to deport them. The Australian authorities, it is implied, were behaving in the best interests of Australia. Furthermore, the references to the League of Nations suggested that Australia was carrying out broader agendas as part of its responsibilities as a member of the community of (civilized) nations. What is clear from all of these cases is the importance of an association with prostitution as a criterion for exclusion, regardless of the wealth or property of the individual concerned. Nor were women the only targets of these deportations: men believed to be involved as procurers or associates of prostitutes were also excluded. This case also demonstrates that it was not only the right to citizenship that was contested in this period: clearly the nature of commercial sex was also open to different interpretations and representations. While the government and press were keen to use "white slave" terminology, the situation of the women and their male companions, as reported both by the police and by themselves in evidence, suggests that the relationship was a far cry from the popular idea of white slavery. The women concerned were neither young nor inexperienced, nor did they appear to be vulnerable to the men with whom they associated. However, by evoking the discourse of white slavery, the government was able to secure greater legitimacy for its actions.

\section{THE WHITE AUSTRALIA POLICY AND THE WHITE} SLAVE TRAFFIC: THE EARLY TWENTIETH CENTURY

Given official attitudes to foreign sex workers and entrepreneurs in the colonial period outlined above, this about-face calls for some explanation.

24. Age, 13 July 1928.

25. Advertiser, 13 July 1928 . The difference of opinion on the basis of citizenship perhaps reflects the distinction identified by Rogers Brubaker, that is, between $j u s$ sanguinis and jus solis, between a principle of descent and a principle of residence. While Germans, for instance, in the nineteenth century emphasized nationality and German descent as qualifications for citizenship, the French state remained much more open to the naturalization of residents who had planted themselves in 
The decision to exclude so-called "white slavers" was clearly not based on any dramatic increase in the traffic in women. Police records and press reports from the colonial period show that contemporaries were aware that there was a niore or less organized movement of sex workers to Australia from Japan via South East Asia on the one hand and from Europe via the Middle East on the other. ${ }^{26}$ The change over the first decades of the twentieth century is only partly explained by the fact that Japanese women ceased to come to Australia after 190I. Equally important is the changing popular perception of this traffic which increasingly saw the international movement of prostitutes as a "white slave traffic", involving an element of coercion.

By the late 1890 s there were already signs of this change in attitude. Obviously inspired by W.T. Stead's campaigns in England, stories began to appear in the press about "white slavers" who lured innocent young girls to the colonies and then forced them into a life of prostitution. ${ }^{27}$ In the popular imagination, the white slave traffic increasingly came to refer to forced prostitution, through violence or deception. Arguably, these narratives of white slavery served a similar function to earlier captivity narratives in defining the emergent Australian nation. ${ }^{28}$ Colonial captivity narratives tended to place white women as captives of "savage" indigenous people: the barbarous treatment received by such captured white women justified the violent dispossession of their captors by white men, and redefined the dispossessors as the rightful owners of the land. The rescue of captured white women symbolized the restoration of the white nation to its legitimate place. Historians have already noted how the fear of "miscegenation" between Asian men and white women was a prominent feature of the move to exclude all Asians from Australian colonies in the late nineteenth

French cultural soil. Rogers Brubaker, Citizenship and Nationhood in France and Germany (Cambridge, 1992). See also Charles Tilly, "Citizenship, Identity and Social History", International Review of Social History, 40 (1995), Supplement 3, pp. 8-10.

26. E.g. D.C. Sissons, "Karayuki-san: Japanese Prostitutes in Australia, $1887-1916$ ", Historical Studies 17 (1977), pp. 323-341 and 474-488; Charles van Onselen, Studies in the Social and Economic History of the Witwaterstand: New Babylon (Harlow, 1982); Ronald Hyam, Empire and Sexuality: The British Experience (Manchester, 1990); Raelene Davidson, "Prostitution in Perth and Kalgoorlie and on the Eastern Goldfields, 1895-1939" (M.A. thesis, University of Western Australia, 1980). 27. Raelene Frances, "Australian Prostitution in International Context", Australian Historical Studies, 106 (1996), pp. 128-129.

28. Carroll Smith-Rosenberg, "Captured Subjects/Subject Others: Violently Engendering the New American", Gender and History, 5 (1993); see also June Namias, White Captives: Gender and Ethnicity on the American Frontier (Chapel Hill, NC, 1993). For Australian captivity narratives, see Kay Schaffer, In the Wake of First Contact: the Eliza Fraser Stories (Cambridge, 1995); Kate DarianSrnith, "Rescuing' Barbara Thompson and Other White Women: Captivity Narratives on Australian Frontiers", in Kate Darian-Smith, Liz Guner and Sarah Nuttall (eds), Text, Theory, Space: Land, Literature and History in South Africa and Australia (London and New York, 1996), pp. 99I14; Kate Darian-Smith, et.al. (eds), Captive Lives: Australian Captivity Narratives (London, 1992). 
century. ${ }^{29}$ In the twentieth century, narratives of "white slavery" continued to feature "lecherous Asiatics" as major villains responsible for the sexual slavery of innocent white girls. ${ }^{30}$ Late nineteenth-century narratives also frequently identified "continental" men as the debauchers and enslavers of British women. These narratives had similar kinds of symbolic significance to that attributed to the frontier captivity narrative: the innocent white woman comes to stand for the white Australian nation, and her rescue from her captors symbolizes Australia's reclaiming of a purer, British identity from degenerate continental Europeans and Orientals. Such stories encouraged a narrow British identification of "white Australia" and harsher punitive measures against "foreigners". The police were urged to take action against the men who were seen as the main instigators of this trade, and politicians were encouraged to change the law to make tougher penalties for so-called "bludgers", or men who lived off the earnings of prostitutes.

A sensational case against an Italian procurer in 1902 marked a turning point in official response to foreign sex workers and entrepreneurs. ${ }^{31}$ At the same time, this case attracted international scrutiny which encouraged the Australian authorities to adopt a harder line against "white slavers". The flow of information was thus not a one-way process: while Australian audiences had eagerly devoured reports of the English Stead case, stories about what was happening in Australia filtered back to England where they added fuel to the growing international campaign against the "white slave traffic".

One example of this is a booklet entitled The White Slave Market. Written around I909 by a Mrs Archibald Mackinolty (Olive Christian Malvery) and W.N. Willis, it advocated a series of legal reforms to deal with the traffic in women:

What we want to do is to get some laws passed in England and in our colonies and our dependencies, and especially in the East - laws such as now exist in Australia, which within a year killed the traffic in women. Two men were captured in Australia with a batch of girls whom they had brought over from Europe, and whom they took to a certain mining camp and sold to a bad life. The men were captured and imprisoned for ten years, and during that period they received several floggings at intervals. There has never been a case of white slave traffic in Australia since these cases were dealt with, and there never will be as long as it is known that to traffic in a girl means a flogging as well as ten years' rigorous imprisonment. ${ }^{32}$

29. A.T. Yarwood, Attitudes to Non-European Immigration (Sydney, NSW, 1968); Raymond Evans, Kay Saunders and Kathryn Cronin, Race Relations in Colonial Queensland 1975 (Brisbane, QLD, 1993), Part III.

30. See, for example, the "drama in four parts", The White Slave Traffic by Kate Howard, written in the 1920s, AA Series A1336/2, item 3432; also Frances, "Australian Prostitution", pp. 136-137.

31. Sunday Times, 24 August 1902.

32. Mrs Archibald Mackinolty (Olive Christian Malvery) and W.N. Willis, The White Slave Market, colonial edition (London, n.d. ca. 1909), p. 94. This account exaggerates the sentences meted out: the men concerned received only two years' hard labour. 
The prosecution of Cozzi, the man referred to above, coincided with an increase in international concern about the traffic in women. The international movement arising from this concern had close connections with existing "abolitionist" groups who sought an end to all systems of stateregulated prostitution. The first international congress on the white slave traffic was held in London in 1899 , and this was followed by the first international convention for the suppression of the white slave traffic in Paris in 1904. The Commonwealth government overcame the initial reservations of several of the states and followed Britain's lead in ratifying the terms of this agreement in 1906. Another international convention was signed in 1910 and Australia adhered to this also in I9I $4 .{ }^{33}$ Australian feminists were active in this campaign at both a local and international level. Being amongst the few enfranchised women in the world at the time, Australian feminists felt a responsibility to take a leading role in the international battle to improve women's status. Indeed, Millicent Garrett Fawcett, in her capacity as First Vice-President of the International Woman Suffrage Alliance, wrote to the Australian prime minister in 1913 to urge the Australian government to conduct an inquiry into the white slave traffic. In support of her case she wrote:

It was pointed out by many delegates [to the Seventh Congress of the International Woman Suffrage Alliance] from countries where women have the vote, that one of the first uses to which women have put their newly acquired political power, was to strengthen the law for the prevention of commercialized vice and for the protection of the young of both sexes. A delegate from Australia informed the Congress that the existence of women voters in Australia had enabled the women of the Commonwealth to insist upon a vigorous and impartial administration of the laws for the repression of the White Slave Trade and kindred evils, with such satisfactory results that commercialized vice had been very greatly diminished in Australia. ${ }^{34}$

The delegates to this congress resolved to urge their own governments to "institute an international enquiry into the extent and causes of commercialized vice" and to "institute a national enquiry along the same lines". The Commonwealth government was not prepared to take any action, believing it had already done everything within its powers under the Immigration Restriction Act. The prime minister suggested the matter would be more appropriately dealt with by the state governments. ${ }^{35}$ However, Australian authorities were not convinced that traffic in women was a serious problem in Australia and the 1914 Premiers' Conference refused to hear from a

33. AA Series Arro8, item vol. 31. Sheila Jeffreys, The Idea of Prostitution (Melbourne, VIC, 1997); ch. I, contains a brief history of these international conventions.

34. Letter Millicent Garrett Fawcett to Andrew Fisher, 17 November 1913, AA Series A1/1, item $1915 / 5651$.

35. Letter from the prime minister to Miss A.B. Witham, hon. secretary, Women's Non-Party Political Association of South Australia, 13 November 1913, AA Series Arro8, item 31. 
delegation, led by the Women's Political Association of Victoria, on the issue. ${ }^{36}$

What is especially significant about the lobbying of feminists and the response of politicians is the way the focus on the white slave traffic deflected attention from the sexual exploitation of Aboriginal women within Australia exposed at the time by the Roth royal commission in 1905. In 1914, the premier of Western Australia could thus write without fear of contradiction, that "the procuration of white women for immoral purposes is not now practised". For feminists, the focus on the white slave traffic encouraged a blindness where the traffic in non-white women was concerned. ${ }^{37}$

\section{THE WHITE AUSTRALIA POLICY AND THE WHITE SLAVE TRAFFIC: WORLD WAR I AND THE LEAGUE OF NATIONS}

The outbreak of war in 1914, however, was to mark a new departure in the history of government and feminist reactions to the international sex industry. Australian troops fighting in the Middle East frequented the brothels of Cairo, a fact that was generally known both to the authorities and to feminist organizations in Australia. ${ }^{38}$ This intercourse drew attention both to the extent of the traffic in women in Egypt and also heightened concern about the relationship between prostitution and venereal disease, and especially about the importation of new, "foreign" strands of the disease to Australia. ${ }^{39}$ After the war, feminist concerns about the traffic in women overlapped with eugenicist fears about the impact of sexually-transmitted diseases on racial vigour. The postwar Australian government shared the fears about racial decline and was also concerned that Australia be seen to acquit itself well as a "civilized" and "advanced" society on the international stage. When the League of Nations took over the administration of the international conventions on the traffic in women, Australia was keen to become a signatory and to carry out its obligations under the convention. ${ }^{40}$ By the middle of the I920s, most Australian governments no longer regarded the presence of foreign prostitutes as beneficial or even benign. The advent of the white Australia policy had meant an end to the importation of

36. AA Series Ar, item 1915/565I; also AA Series Arro8, item vol. 3I.

37. Letter J. Scadden, premier of Western Australia, to prime minister, 6 July 1914, AA Series Arro8, item vol. 31. See also Raelene Frances, "Australian Prostitution in International Context", Australian Historical Studies, 106 (1996), pp. 129-130.

38. AA series $\mathrm{CP}_{7} 8 / 23 / \mathrm{r}$. item 14/89/252 $\mathrm{Pt} 1$; Bruce Scates and Raelene Frances, Women and the Great War (Cambridge, 1997), ch. 6.

39. Judith Smart, "The Great War and the 'Scarlet Scourge': Debates about Venereal Diseases in Melbourne during World War I", in Judith Smart and Tony Wood (eds), An Anzac Muster: War and Society in Australia and New Zealand 1914-18 and 1939-45 (Clayton, VIC, 1992), pp. 58-85.

40. The first two conventions ( 1904 and 1910 ) were administered by the French government. 
"coloured" Pacific Island and Chinese labourers and the enforced repatriation of most of Australia's existing "coloured" populations. The racial rationale for tolerating foreign prostitutes to service a large non-white male population no longer existed. Japanese prostitutes were themselves victims of the new immigration laws: the door was firmly closed against new arrivals while most already in Australia were required to leave. French prostitutes were now targeted as the main contaminating influence, both morally and physically. After Australia's experiences during the war, it was not hard for the government to be convinced that a traffic in women did exist and that the Middle East had a particular role to play as a staging post en route to Australia and the Orient. In 1927 the director of the Attorney General's Department referred to impending Commonwealth action due to "a growth in the obnoxious traffic in this country, organized in Alexandria and Port Said". ${ }^{41}$

It was also very convenient for Australians to blame foreigners for the traffic, as this reinforced national stereotypes which had achieved greater clarity during the war. Thus in 1931, the director of the Commonwealth Attorney General's Department informed the secretary of the Prime Minister's Department that: "This gravamen [i.e. persons living on immoral earnings of women] is very rarely discernible among Australians of British descent, as such a practice is repugnant to national ethics. The infrequent cases discovered have been perpetrated by aliens, [...]. ${ }^{n 2}$ The fact that the League of Nations had endorsed the issue of the traffic in women gave it an added validity which it had lacked when the main proponents of the convention could be dismissed as "hysterical" feminists and religious enthusiasts. The endorsement of the League also meant that there was one central bureaucrat in Australia who had the responsibility of monitoring the traffic and reporting back to the League. All these factors combined to ensure that the matter was treated with much greater seriousness after the war than it had been before.

Having decided that some action needed to be taken, it is not hard to see why the policy of exclusion commended itself to the authorities. As the director of the Attorney General's Department explained:

As principal executive officer in Australia under the White Slave Convention of the League of Nations, I am of opinion that one of the best practical methods of dealing with the question of White Slavery is to make it impossible for the unscrupulous foreigners to import women of the unfortunate class to Australia, and that the best way to do this is to deport any such women who manage to enter and who immediarely practise their profession here. ${ }^{43}$

41. Letter, H.E. Jones, director, Attorney-General's Department, to the secretary, Home and Territories Department, 29 July 1927, AA Series 2998/I, item 51/576.

42. Memo, io November 1931, AA Series A98I/1, item League Wom/II.

43. Letter, H.E. Jones, director, Attorney-General's Department, to the secretary, Home and Territories Department, 29 July 1927, AA Series 2998/1, item 51/576. 
The fact that immigration policy was centrally determined under the Commonwealth made a uniform Australian response to the issue possible, unlike during the nineteenth century when each colonial government devised its own policy. After federation, immigration policy was the one area of control that the Commonwealth government had over the sex industry. Policing as such remained a state concern. Indeed, as the subsequent history of Australia's involvement with international conventions shows, the unwillingness of certain states to adopt policing policies favoured by the Commonwealth government was to prevent Australia becoming a signatory until the 1970 s to the more stringent abolitionist conventions under the United Nations. ${ }^{44}$ The major problem was that a de facto type of regulation of prostitution had existed in Queensland and Western Australia for several decades. After the war, international pressure to abolish regulation was becoming stronger, and scrutiny of Australia's policing methods more sweeping. The Commonwealth government attempted to deflect such international criticism by semantic twists in their response to inquiries from the League. For instance, when in 1926 the League inquired about the existence of licensed houses of prostitution, the official response had to be carefully worded. As the prime minister's secretary noted on the file, "The point is that the System is not authorised in any of the States [...]" [original emphasis]..$^{45}$ Exclusion of alien prostitutes and procurers had the attraction of being uncontroversial in Australia whilst also enabling Australia to present an enlightened face to the rest of the world on the white slave issue.

The effects of Australia's approach to the "white slave traffic", however, were much more ambiguous from the point of view of the abolitionists. As we have seen, the activities of the International Abolitionist Federation and the various conventions which it spawned had considerable impact on immigration policy and policing within Australia. Activists would no doubt have been most gratified at the exclusion or deportation of men allegedly involved in trafficking in women. However, the wholesale deportation of foreign prostitutes, which was carried out as a government strategy to discourage the international movement of sex workers, was more problematic from a feminist perspective. Indeed, the question of the compulsory repatriation and exclusion of prostituted women was a contentious issue in the League of Nations forums, with feminists and civil libertarians arguing

44. See AA Series $1838 / 1$, item $856 / 14 / 8$, part 4. "Abolitionists" sought the abolition of the system of policing prostitution known as regulation, that is, a system whereby prostitutes were required to register with the local police and subject themselves to regular medical examination. The incorporation of the abolitionist principle was first adopted by the Traffic in Women and Children Committee in 1936, and expressed in the 1937 Draft Convention for Suppressing the Exploitation of the Prostitution of Others. However, the outbreak of World War II delayed developments of this draft. AA Series Ar8382, item $856 / 14 / 8$, pt. I.

45. File note on report on licensed houses for transmission to Secretary-General, League of Nations, 7 October 1926, AA Series A981/t, item League Wom/11. 
against discriminatory measures. As debates in the League's International Bureau for the Suppression of the Traffic in Women show, civil libertarians were alive to the potential for official abuse of any such measures. Monsieur Reelfs of Switzerland also pointed out that such repressive measures meant that: "The prostitute was being considered as a special class which could be driven from place to place. ${ }^{n} 46$ The women who were subsequently deported from Australia had left Egypt in the wake of changes brought about by the activities of the International Bureau for the Suppression of the Traffic in Women, working in conjunction with the local police. The Vigilance Record, for instance, reported in 1929 that: "Port Said, notorious for its traffickers a few years ago, is now a reformed City. Owing to the vigilance of the Police and the work being done by the local branch of the International Bureau, Port Said is utterly changed. ${ }^{37}$ As the official files relating to the 1920 s deportations show, many, perhaps even most, of the women who came to Australia from France via Egypt intended to become long-term residents. They brought property and established businesses in the relatively lucrative and safe environment of Roe Street in Perth. These women became the unintended victims of the anti-trafficking campaign, forced to sell their property at a loss and to leave a country where they had hoped to achieve modest comfort and security. Indeed, it could be argued that deportation prolonged the working life of prostitutes by forcing them to recoup their Australian losses.

\section{THE DICTATION TEST: AN INTERNATIONAL VAGRANCY LAW?}

Given the obvious attractions of a policy of exclusion, the question remains as to why the government chose to use the dictation test, originally designed to exclude non-Europeans, against people engaged in the sex industry. The question needs to be asked because the original Immigration Restriction Act specifically prohibited the entry of "any prostitute or person living on the prostitution of others". The 1912 Amending Act added the word "procurer" after "prostitute".$^{48}$ Initially it seems the government relied on this clause. ${ }^{49}$ However, increasingly the authorities came to prefer the dictation test because it gave them much more flexibility: it did not require the same kind of proof necessary to proceed under the more specific clause. As the director of the Artorney General's Department put it, "a distinct charge under this

46. International Bureau for the Suppression of the Traffic in Women and Children, Congress Reports, London, 1930, cited in Jeffreys, The Idea of Prostitution, p. 24.

47. Extract from Vigilance Record, March-April 1929, in International Bureau for the Suppression of the Traffic in Women Papers, Josephine Butler Archives, Fawcett Library, London, ms. $4 / 1 \mathrm{BS}$, box in2.

48. Letter, Atlee Hunt to Hon. P. McGlynn, 30 March I9I5, AA Series AI, item 1915/5651.

49. Ibid. 
category is not laid unless the evidence is convincing". Undeterred, however, immigration authorities "invariably charged" "the culprit" with being a prohibited migrant, using the dictation test. The "culprit" was "always deported". Indeed, the effectiveness of this clause, and the inevitable failure of any appeals, eventually ensured that the mere threat was sufficient to ensure the persons targeted left the country. ${ }^{5 \circ}$

The dictation test thus came to assume a similar role in the international arena that the vagrancy law performed for local policing. Sue Davies's observations about vagrancy laws can thus be applied with equal validity to the dictation clause of the Immigration Restriction Act:

Vagrancy laws, in general, were distinct from other criminal legislation because of their preoccupation with character, and their inherent breadth and flexibility. They allowed a degree of discretion in their application, and could therefore be used as a catch-all. In Victoria, and in Britain, the vagrancy provisions were used to prosecute not only the criminal, but also the suspected and the innocent. ${ }^{5 \mathrm{~T}}$

As noted earlier, the vagrancy clauses of the Police Act were used in Western Australia to enforce a type of de facto regulation of prostitution. Davies's comments about the arbitrary authority of the vagrancy laws are equally applicable to the dictation test. This is nowhere more clearly illustrated than in the case of Mrs Mabel Freer, who was refused permission to enter Australia in 1936 .

Mrs Freer was the Indian-born daughter of an English army pensioner and his British wife. In 1936 she was an attractive twenty-six-year-old mother of two, divorced from her English husband, residing in Bombay. Sometime during 1936, whilst living apart from her husband, Mrs Freer met and fell in love with a young Australian army officer. $\mathrm{He}$, too, was unhappily married and separated from his wife. He decided to return to Australia and organize a divorce and she accompanied him on the same ship, hoping to marry him in due course. Unfortunately, their plans were thwarted by the intervention of the Australian Department of Immigration. The young lieutenant's father-in-law, concerned at the course of events, lobbied acquaintances in the army who used their position to persuade the immigration authorities that Mrs Freer was an undesirable immigrant. When the boat carrying the couple reached Fremantle in October 1936, Mrs Freer was given a dictation test in Italian, which not surprisingly she failed. She was promptly declared a prohibited immigrant under the Immigration Restriction Act. Mrs Freer subsequently was given permission to transship to New Zealand, where she appealed against her fate for eight months before finally being allowed to enter Australia. In the meantime, however, she became

so. See memo io November 1931, director, Attorney General's Department to secretary, Prime Minister's Department, AA Series A98I/r, item League Wom/II.

รI. Suzanne Davies, "Vagrancy and the Victorian Social Construction of the Vagrant in Melbourne, 1880-1907" (Ph.D. thesis, Melbourne University, Melbourne, VIC, 1990), pp. I15-116. 
something of cause celebre in the Australian press: because the Immigration Department refused to give any reason for her exclusion, the public had no limit when it came to speculation. Was she a spy or a dangerous subversive? Was she a woman of ill-fame? Even engaged in the white slave traffic? Was she a "dope fiend"? Was she, perhaps, really of mixed English and Indian descent? Even when the federal cabinet learned the real history of the case and eventually decided that she should be admitted to Australia, no official explanation was given nor any apology or compensation. As Mabel Freer put it, her "character was ruined".$^{2}$ Her solicitor protested to the Australian Attorney-General, "It seems hard to believe that any Government would, in light of the circumstances [...] go so far as to exclude a British citizen from its territory." In his opinion, the way in which the dictation test was used constituted a breach of the basic principles of British justice: a denial of the "primary right to which every British subject is entitled - open accusation and open opportunity for reply".53

The reason for this denial of natural British justice was the fact that the Immigration Restriction Act targeted those who transgressed either (or both) the racial and moral ideals of white Australia. Like the vagrancy laws, the dictation test was used to police women's sexuality. Sex workers were an obvious target, but clearly any woman whose sexuality seemed to contravene the ideal of exclusive marital relationships was also vulnerable. Like the sex workers deported in 1929, Mrs Freer was excluded despite her class background. The Freer case shows not just the arbitrary power available to immigration officials under the Act, but also the increasingly narrow definition of "white Australia" between the two world wars. The dictation test gave immigration officials the flexibility to respond to this narrowing definition without having to resort to legislative changes.

\section{REASSESSING WHITE AUSTRALIA AND THE WHITE SLAVE TRAFFIC BETWEEN THE WARS}

It is ironic that just as Australia achieved its peak of "whiteness" in the I930s, the first signs of a fundamental reassessment of Australia's racial policies and practices were appearing. After the First World War, and the advent of the League of Nations, there was a much greater international awareness that the use of the term "white slave traffic" was misleading. This was reflected in the change of name for the 1921 convention to Convention for the

52. Letter from G.P. Finlay, barrister and solicitor, Wellington, NZ, to the Attorney-General of the Commonwealth of Australia, II November 1936, Australian Archives (AA) Series A 432/85, item 36/1360. The Mabel Freer case is documented in the following files, held at the Australian Archives in Canberra: Series CP 290/1/1, item 16; Series $A_{422} / 85$, item 43/1139; Series $A_{432} / 85$, item 36/1360; Series A5954/I, item 973/13.

53. Letter from G.P. Finlay, barrister and solicitor, Wellington, NZ, to the Attorney-General of the Commonwealth of Australia, Ir November 1936, AA Series A432/85, item 36/1360. 
Suppression of the Traffic in Women and Children. In Australia, however, the full implications of this change were only slowly recognized. As recent work in this area shows, the Australian feminist movement did not become active on the issue of the sexual exploitation of Aboriginal women until 1927. ${ }^{54}$ This sudden interest in the plight of Aboriginal women seems to have been prompted as much by events overseas as by developments in Australia. Australian women participating in international conferences in the mid-I920s, such as those organized by the League of Nations, the AntiSlavery Society, the International Women's Suffrage Alliance and the British Commonwealth League, returned to Australia with a feminist agenda which emphasized the plight of Aboriginal women in a way that previous agendas had not. ${ }^{5 s}$ Mary Montgomerie Bennett was one of the most prominint of these activists. In 1934 she wrote of her concern about what she termed the "white slave traffic in black women" in Western Australia's Kimberley region, where she reported that pastoralists, pearlers and other men were using Aboriginal women as "merchandise" ${ }^{56}$ Yet, as earlier noted, this situation was hardly new: the sexual exploitation of Aboriginal women had been a feature of the colonization process across Australia since 1788.57 The tardiness of Australian feminist responses to this issue is perhaps a product of the consciousness produced by the earlier concentration on "white slavery", with the typical victim being an innocent white girl at the mercy of foreign men, rather than a black woman being sexually exploited by a white man. The shift in attitudes in the late 1920 s was made possible partly by the changing international awareness that the traffic in women and children also involved non-white women and children, and partly by a renewed concern with slavery generally. Indeed, the international anti-slavery movement of the 1920 was the more powerful influence on women such as Mary

54. Alison Holland, "Feminism, Colonialism and Aboriginal Workers: An Anti-Slavery Crusade", in Ann McGrath and Kay Saunders with Jackie Huggins (eds), Aboriginal Workers, a special issue of Labour History, 69 (1995); Alison Holland, "Saving the Aborigines': The White Woman's Crusade. A Study of Gender and Race on the Australian Frontier", (Ph.D. thesis, University of New South Wales, 1999); Fiona Paisley, “'Don't Tell England!': Women of Empire Campaign to Change Aboriginal Policy in Australia Between the Wars", Lilith: A Feminist History Journal, 8 (1993), pp. 139-I52; Fiona Paisley, "Feminist Challenges to White Australia 1900-1930s", in Diane Kirkby (ed.), Sex, Power and Justice: Historical Perspectives on Law in Australia (Melbourne, VIC, 1995), pp. 252-269; Marilyn Lake, "Feminism and the Gendered Politics of Anti-Racism, Australia 1927-1957: from 'Maternal Protectionism to Leftist Assimilationism' ", Australian Historical Studies, IIO (1998), pp. 9I-I08.

55. The importance of international influences on Australian feminists in this case has interesting resonances to the growth of the interest in issues of sexual domination, prostitution, venereal disease and the "white slave traffic" in the prewar period. See Barbara Caine, "Vida Goldstein and the English Militant Campaign”, Women's History Review, 2 (1993), pp. 363-376.

56. Bennett to Australian Board of Missions Review, Rischbieth Papers, MS 2004/12/35, National Library of Australia, cited in Lake, "Feminism and the Gendered Politics of Antiracism", p. Ioo. 57. Raelene Frances, "A History of Female Prostitution in Australia", in Roberta Perkins, et.al. (eds), Sex Work and Sex Workers in Australia (Kensington, NSW, 1994). 
Bennett. Fiona Paisley has suggested that the activism of Australian feminists in the late I920s and I930s reflected a less defensive strand in relation to Australian nationalism and a greater willingness to risk embarrassing the Australian government in order to advance the cause of Aborigines. ${ }^{58} \mathrm{I}$ would also argue that as Australia became more confident as a "white nation" in the interwar period, some of its white citizens became less concerned with policing the borders of white Australia and more prepared to reconsider the fate and rights of its indigenous population. The white slave traffic, and attitudes towards it, were an important part of this shifting definition of citizenship.

\section{CONCLUSION}

Ann Curthoys has argued that writing a history which embraces the interrelationships between race, class and gender presents almost insuperable difficulties:

Trying to keep just two of these concepts in play has proved extremely difficult [...]. But if keeping two such concepts in play is hard enough, look what happens when the third concept, be it ethnicity or class or sex, is brought seriously into play. The system, the analysis, becomes too complex to handle..$^{99}$

By focusing on the issue of prostitution, I hope to have overcome some of the difficulties presented by "the three body problem". I have argued that since the inception of white occupation, the sex industry has played a critical part in the way in which governments attempted to construct a society within a particular configuration of racial/ethnic, sex/gender and class factors. However, the precise relationship of these factors to each other, both in the official vision and in practice, varied considerably over time and place.

Initially, maintaining a particular class hierarchy and heterosexual norm assumed primacy over any considerations of racial hierarchies. Official priorities, however, were quickly modified in the light of popular attitudes and colonial realities. As white society achieved supremacy over the indigenous population, and non-white labourers were imported, particularly in the north, the preservation of white supremacy ensured that racial considerations became a major issue for colonial governments and important presssure groups within white colonial society. However, the very fact that racial hierarchies were an issue meant that questions of class and status were inextricably linked. Similarly, the predominance of men over women in most non-white immigrant ethnic groups required careful management of the sex industry to ensure that sexual access of "coloured" men to white

58. Fiona Paisley, “'Don't Tell England!'”.

59. Ann Curthoys, "The Three Body Problem: Feminism and Chaos Theory", in Women/Australia/Theory, special issue of Hecate, 17 (1991), p. I5. 
women did not arise as a disturbing element in the colonial social order. On the other hand, white men's access to Aboriginal women formed part of the process of dispossession and domination of indigenous people.

In the early twentieth century, as Australia redefined itself as a modern, independent, "civilized" white nation, racial issues assumed a different, less visible, but equally important role. White men's access to Aboriginal women was now officially deplored as a threat to white racial purity and vigour, but unofficially and clandestinely practised on a large scale. Strict immigration controls ensured that "coloured" labourers were prohibited from entering Australia. The movement of sex workers between Australia and overseas countries came to be seen as a threat both to the racial vigour of Australia's white population and a threat to Australia's standing in the international community. Race was still the issue, but it was defined differently, with "white" increasingly coming to mean British rather than European. Likewise, race was inextricable linked to the maintenance of a white society with a particular class basis. Whereas in the colonial period "coloured" immigrant workers existed as a cheaper rung of the working class, federated Australia deliberately turned its back on such a racially defined sub-class. While immigrant "coloured" workers and their descendents were deported in large numbers, it was not so easy for governments to dispose of the indigenous "coloured" population who also occupied the role of a subservient, poorly paid workforce. ${ }^{60}$ As the century progressed it became clear that Australians of Aboriginal descent were increasing in number rather than decreasing according to Social Darwinist prescription. By the end of the 1930 s their plight was becoming visible to increasing numbers of white Australians, who were forced to rethink the nature of the so-called "white Australia". The international movement against the "white slave traffic", with its new sensitivity to the exploitation of non-white women, provided a gendered lens through which the class relationship of Aboriginal peoples to white Australia could be reassessed.

6o. There is now an extensive literature on this subject, which is reviewed in Ann Curthoys and Clive Moore, "Working for the White People: an Historiographical Essay on Aboriginal and Torres Strait Islander Labour", in Ann McGrath and Kay Saunders with Jackie Huggins (eds), Aboriginal Workers, special issue of Labour History, 65 (1994). See also Andrew Markus, "Aborigines in Labour History", in Jim Hagan and Andrew Wells (eds), Australian Labour and Regional Change: Essays in Honour of R.A. Gollan (Wollongong, NSW, 1998), pp. 41-56; and Raelene Frances, Bruce Scates and Ann McGrath, "Broken Silences? Labour History and Aboriginal Workers", in Terry Irving (ed.), Challenges to Labour History, (Kensington, NSW, 1994), pp. 189-211. 